\title{
Carla- and Potyviruses detected in garlic plants
}

\section{Carla- i potywirusy wykrywane w czosnku pospolitym}

\author{
Maria Bereda, Elżbieta Paduch-Cichal*
}

\section{Summary}

Garlic (Allium sativum L.) has been a well-known spice as well as a popular medicinal plant. Vegetative propagation of garlic is an efficient means of viruses transfer. Apart from the viruses of Allexivirus genus, which are known as garlic pathogens, the most common virus detections are Potyvirus and Carlavirus. Onion yellow dwarf virus (OYDV) and Leek yellow stripe virus (LYSV) from genus Potyvirus (family Potyvirdae), whereas Garlic common latent virus (GarCLV) and Shallot latent virus (SLV) belonging to the genus Carlavirus (family Betaflexiviridae) are most frequently detected in garlic plants.

Key words: garlic; Carlavirus; Potyvirus; allexiviruses; genome; genetic diversity

\section{Streszczenie}

Czosnek pospolity (Allium sativum L.) jest znaną od dawna rośliną przyprawową oraz bardzo popularną rośliną leczniczą. Rozmnażanie wegetatywne czosnku jest łatwą drogą przenoszenia wirusów. Oprócz wirusów z rodzaju Allexivirus, dla których czosnek jest jedynym znanym gospodarzem, najczęściej wykrywane są wirusy rodzaju Potyvirus i Carlavirus. Wirus żółtej karłowatości cebuli (Onion yellow dwarf virus, OYDV) i wirus żółtej pasiastości pora (Leek yellow stripe virus, LYSV) należą do rodzaju Potyvirus (rodzina Potyvirdae), zaś zwykły utajony wirus czosnku (Garlic common latent virus, GarCLV) i utajony wirus szalotki (Shallot latent virus, SLV) zaliczane są do rodzaju Carlavirus (rodzina Betaflexiviridae) i są najczęściej wykrywane w roślinach czosnku pospolitego.

Słowa kluczowe: czosnek pospolity; carlawirusy; potywirusy; genom; zróżnicowanie genetyczne

\footnotetext{
Szkoła Główna Gospodarstwa Wiejskiego w Warszawie

Samodzielny Zakład Fitopatologii

Nowoursynowska 159, 02-776 Warszawa

*corresponding author: elzbieta_paduch_cichal@sggw.pl
} 


\section{Wstęp / Introduction}

Czosnek pospolity (Allium sativum L.) jest od kilku tysięcy lat znany i stosowany jako przyprawa i środek leczniczy.

Podobnie, jak wiele gatunków drzew i krzewów owocowych, rozmnażany jest jedynie w sposób wegetatywny, ponieważ większość uprawianych odmian nie zawiązuje nasion (Etoh 1985; Simon i Jenderek 2003). Duże, graniczące $\mathrm{z}$ pewnością, prawdopodobieństwo przeniesienia wirusa na nową roślinę w toku wegetatywnego rozmnażania sprawia, że choroby wirusowe są szczególnym problemem w uprawach czosnku pospolitego.

Z roślin czosnku pospolitego wyizolowano kilka różnych gatunków wirusów. Część z nich była dotychczas znana jako patogeny monofagiczne, infekujące jedynie czosnek pospolity (rodzaj Allexivirus, rodzina Alphaflexiviridae). Nowe doniesienia świadczą jednak, że gatunki należące do rodzaju Allexivirus mogą mieć więcej żywicieli (Fidan i wsp. 2015). Gatunki należące do innych rodzajów porażają obok roślin czosnku, wiele innych gatunków. Spośród polifagicznych wirusów, najczęściej wykrywane w czosnku pospolitym gatunki należą do rodzaju Potyvirus i Carlavirus. W latach 90. XX wieku, van Dijk i wsp. (1991), van Dijk (1993a, b) oraz Barg i wsp. (1997) podjęli próbę identyfikacji gatunków wirusów należących do rodzaju Potyvirus i Carlavirus porażających rośliny czosnku pospolitego (A. sativum).

Wirus żółtej karłowatości cebuli (Onion yellow dwarf virus, OYDV) i wirus żółtej pasiastości pora (Leek yellow stripe virus, LYSV) należące do rodzaju Potyvirus (rodzina Potyvirdae) oraz zwykły utajony wirus czosnku (Garlic common latent virus, GarCLV) i utajony wirus szalotki (Shallot latent virus, SLV) z rodzaju Carlavirus to patogeny najczęściej porażające rośliny czosnku pospolitego.

\section{Wirus żółtej karłowatości cebuli - występowanie, szkodliwość, epidemiologia / Onion yellow dwarf virus - occurrence, harmfulness and epidemiology}

Wirus żółtej karłowatości cebuli został po raz pierwszy opisany przez Bos w 1976 roku na cebuli zwyczajnej (Allium cepa L.), u której obserwowano żółtą pasiastość i deformacje liści oraz zahamowanie wzrostu roślin. Gatunek ten został wykryty także w roślinach czosnku pospolitego i zidentyfikowany jako OYDV przy użyciu technik immunoelektronomikroskopowych (Conci i wsp. 1992) oraz technik biologii molekularnej (Kobayashi i wsp. 1996; Tsuneyoshi i wsp. 1998a; Conci i wsp. 1999; Chen i wsp. 2001a).

Dotychczas występowanie OYDV odnotowano na terenach: Afryki: Egipt (Soliman i wsp. 2012), Sudan (Mohammed i wsp. 2013) i Etiopia (Jemal i wsp. 2015), Ameryki Południowej: Wenezuela (Marys i wsp. 1994) i Brazylia (Parrano i wsp. 2012), Australii (Sward i Brennan 1994), Azji: Izrael (Koch i Salomon 1994), Jawa (Sutarya 1994), Indie (Ghosh i Ahlawat 1997; Majumder i wsp. 2008), Chiny (Chen i wsp. 2003), Japonia (Takaki i wsp. 2006), Turcja (Fidan i Baloglu 2009) i Iran (Saffar i wsp. 2013) oraz Europy: Holandia (van Dijk 1993a), Francja (Messiaen i wsp. 1994), Włochy (Bellardi i wsp.
1995), Polska (Szyndel 1997; Chodorska i wsp. 2014c; Winiarczyk i wsp. 2014), Czechy (Klukáčková i wsp. 2004), Niemcy (Celli i wsp. 2013) i Serbia (Milosevic i wsp. 2015).

Wirus żółtej karłowatości cebuli jest głównym składnikiem kompleksu wirusów porażających czosnek pospolity (Takaichi i wsp. 2001; Chen i wsp. 2003). Straty w plonie cebuli zwyczajnej i czosnku pospolitego porażonych przez OYDV wynoszą od 25 do 60\% (Barg i wsp. 1994; Lot i wsp. 1998; Dovas i wsp. 2001). Ponadto, chore rośliny zawiązują mniejszą liczbę nasion (spadek o około $50 \%$ ) oraz przedwcześnie zamierają (Conci i wsp. 2003; Elnagar i wsp. 2011; Kumar i wsp. 2011).

Wyniki badań prowadzonych przez Dovas i wsp. (2001) na terenie greckich upraw wskazują, że skala porażenia roślin czosnku pospolitego przez OYDV może dochodzić do $100 \%$. Shahraeen i wsp. (2008) podają, że wirus był obecny w 91,5\% upraw czosnku pospolitego w Iranie, a we Włoszech, Dovas i Volvas (2003) odnotowali obecność wirusa w 98\% nasadzeń. Podobne wyniki uzyskano podczas badań przeprowadzonych na terenie Czech (Klukáčková i wsp. 2007), Polski (Winiarczyk i wsp. 2014) i Brazylii (Mituti i wsp. 2015), gdzie OYDV był wirusem dominującym w uprawach czosnku pospolitego. Chodorska i wsp. (2014c) po przebadaniu 29 prób pochodzących z polskich upraw, stwierdzili obecność OYDV w 6 próbach pochodzących z odmiany Mega, co stanowiło 20\% porażenie prób czosnku w Polsce. Biorąc pod uwage jedynie próby odmiany Mega, można uznać, że OYDV porażał $60 \%$ prób. Zatem, w oparciu o dane uzyskane przez Chodorską i wsp. (2014c) oraz Winiarczyk i wsp. (2014) stopień porażenia polskich upraw czosnku przez OYDV wynosi 60-75\%.

Wirus żółtej karłowatości cebuli przenoszony jest wraz z materiałem rozmnożeniowym oraz w sposób nietrwały przez różne gatunki mszyc, np. Myzus persicae Sulz. (Melhus i wsp. 1929; Kumar i wsp. 2011).

\section{Wirus żółtej pasiastości pora - występowanie, szkodliwość, epidemiologia / Leek yellow stripe virus - occurrence, harmfulness and epidemiology}

Wirus żółtej pasiastości pora jest drugim gatunkiem, należącym do rodzaju Potyvirus, wykrywanym w roślinach czosnku pospolitego. Został on po raz pierwszy wykryty w Belgii w 1971 roku (Verhoyen i Horvat 1973). Wówczas oceniono, że 40\% upraw czosnku pospolitego było porażone przez LYSV, a w 1972 roku liczba ta osiągnęła wartość 74\%. W latach 1976-1978, w Holandii, Paludan (1980) notował wyraźny wzrost liczby roślin zakażonych przez wirus z 12 do 43\%. W Nowej Zelandii wszystkie testowane próby pora były porażone przez LYSV (Mohamed i Young 1980).

Obecnie specyficzne dla roślin czosnku pospolitego izolaty wirusa (LYSV-G), wykryto i zidentyfikowano w większości rejonów świata, tj. na terenie Ameryki Południowej: Brazylia (Fajardo i wsp. 2001), Ameryki Północnej: Meksyk (Perez-Moreno i wsp. 2006), Azji: Chiny, Japonia i Korea Południowa (Chen i wsp. 2001b; Takaki i wsp. 2005; Navratil i wsp. 2006; Yoshida i wsp. 2012), Indie (Gupta i wsp. 2013; Gawande i wsp. 2014), Europy: Holandia (van Dijk 1993a; Takaki i wsp. 2005), 
Czechy (Navratil i wsp. 2006), Hiszpania (Yoshida i wsp. 2012), Włochy (Parrano i wsp. 2012) i Polska (Chodorska i wsp. 2014a; Winiarczyk i wsp. 2014).

Wyniki badań wskazują, że LYSV jest wykrywany w mniejszej liczbie prób czosnku pospolitego niż OYDV. Wirus ten był stwierdzony w 30\% roślin czosnku pospolitego pochodzących z upraw zlokalizowanych na terenie Czech i Polski (Klukáčková i wsp. 2007; Winiarczyk i wsp. 2014). W Iranie LYSV występował w $40-86 \%$ prób, natomiast na terenie Brazylii wykryto go w 30-46\% roślin (Fayad-André i wsp. 2011; Mituti i wsp. 2015). Badania przeprowadzone przez Chodorską i wsp. (2014b) wykazały, że w czosnku pospolitym pochodzącym z Egiptu i Hiszpanii, znajdującym się w obrocie handlowym na terenie Polski, LYSV występował w 40\% badanych prób.

Straty w plonie czosnku pospolitego porażonego przez LYSV wynoszą od 17 do 60\% (Lot i wsp. 1998; Dovas i wsp. 2001).

Wirus żółtej pasiastości pora przenoszony jest wraz $\mathrm{z}$ materiałem rozmnożeniowym oraz w sposób nietrwały przez mszycę brzoskwiniową ( $M$. persicae) i mszycę trzmielinowo-burakową (Aphis fabae Scop.) (Bos i wsp. 1978).

\section{Potywirusy porażające czosnek pospolity - budowa genomu / Potyviruses associated with garlic plants - genome structure}

Cząstki wirusów należących do rodzaju Potyvirus są nitkowate, mają około $800-820 \mathrm{~nm}$ długości i średnicę około 12-15 nm (Delecolle i Lot 1981). Koch i Salomon (1994) oraz Baghalian i wsp. (2010) obserwowali przy użyciu mikroskopu elektronowego w preparatach wykonanych z roślin czosnku pospolitego obecność nitkowatych cząstek długości 700-800 nm oraz $12 \mathrm{~nm}$ średnicy morfologicznie odpowiadających cząstkom OYDV.

Genom gatunków należących do rodzaju Potyvirus stanowi jednoniciowy (+) RNA, wielkości około $10 \mathrm{~kb}$. Genom koduje polipeptyd prekursorowy, który następnie ulega cięciu przez trzy proteazy wirusowe (P1, HC-Pro i NIa-Pro) na 10 białek: P1, HC-Pro, P3, 6K1, CI, 6K2, VPg, NIa-Pro, NIb i CP, niezbędnych w cyklu życiowym wirusa (Verma i wsp. 2014). Dane literaturowe wskazują, że fragment genomu izolatów OYDV i LYSV obejmujący gen kodujący białko płaszcza (coat protein, CP) jest najczęściej wykorzystywany do wykrywania i identyfikacji wirusów w roślinach (Riechmann i wsp. 1992; Arya i wsp. 2006).

\section{Zróżnicowanie genetyczne populacji potywirusów pochodzących z roślin czosnku pospolitego / Genetic diversity of Potyvirus populations originated from garlic plants}

Pierwszą pełną sekwencję genomu izolatu OYDV pochodzącego $\mathrm{z}$ naturalnie porażonej rośliny czosnku uzyskał Chen i wsp. (2003). Dostępne w literaturze dane opierają się zazwyczaj na podobieństwie sekwencji nukleotydów genu kodującego białko płaszcza między izolatami wirusa. Badania przeprowadzone przez Chodorską i wsp. (2014b) wykazały, że stopień podobieństwa sekwencji nukleotydów genu kodującego CP dziewięciu polskich izolatów OYDV pochodzących z roślin czosnku pospolitego w stosunku do sekwencji genu kodującego CP australijskiego izolatu MS/SW1 wyniósł $86 \%$. Według Beredy i wsp. (2015) sekwencje nukleotydów genu kodującego CP wszystkich dostępnych w banku genów izolatów OYDV otrzymanych z roślin cebuli zwyczajnej oraz sekwencje nukleotydów genu kodującego CP izolatów z czosnku pospolitego różnią się od siebie na poziomie 12-19\%. Różnica w sekwencji aminokwasów wynosiła 4-14\%.

Pełne sekwencje nukleotydów genomu trzech japońskich izolatów LYSV pochodzących z czosnku pospolitego wykazały podobieństwo na poziomie 98,5\%. Porównanie kompletnych sekwencji nukleotydów i aminokwasów genomu wykonane między tymi izolatami wirusa a chińskim izolatem Zhejiang/China wykazało $76 \%$ podobieństwo na poziomie nukleotydów oraz $81 \%$ na poziomie aminokwasów (Takaki i wsp. 2005).

Z badań Chodorskiej i wsp. (2014a) wynika, że podobieństwo między sekwencjami nukleotydów genu kodującego CP ośmiu polskich izolatów LYSV pochodzących z roślin czosnku pospolitego wahało się od 96 do 99\%. Autorzy uzyskali również sekwencje nukleotydów genu kodującego CP dwóch izolatów LYSV pochodzących Z Egiptu oraz dwóch izolatów LYSV pochodzących z Hiszpanii. Podobieństwo na poziomie nukleotydów między egipskimi izolatami wirusa wynosiło $92-95 \%$ oraz 95-97\% między izolatami hiszpańskimi.

\section{Zwykly utajony wirus czosnku - występowanie, szkodliwość, epidemiologia / Garlic common latent virus - occurrence, harmfulness and epidemiology}

Zwykły utajony wirus czosnku (Garlic common latent virus, GarCLV) należy do rodzaju Carlavirus. GarCLV został uznany za jeden $\mathrm{z}$ najczęściej występujących wirusów w uprawach czosnku pospolitego (van Dijk 1993b; Tsuneyoshi i wsp. 1998b). Wirus został po raz pierwszy wykryty i zidentyfikowany w roślinach czosnku pospolitego we Francji (Delecolle i Lot 1981).

$\mathrm{Z}$ danych zawartych w literaturze tematu wynika, że wirus jest notowany na obszarze: Afryki: Sudan (Hamed i wsp. 2013), Ameryki Południowej: Argentyna (Nicto i wsp. 2004) i Brazylia (Fajardo i wsp. 2001; Parrano i wsp. 2012), Ameryki Północnej: Stan Wahington (Pappu i wsp. 2005) i Meksyk (Pérez-Moreno i wsp. 2007), Australii (Wylie i wsp. 2012), Azji: Japonia, Tajwan i Tajlandia (Barg i wsp. 1994, 1997), Indie (Majumder i Baranwal 2009), Turcja (Fidan 2009) i Chiny (Parrano i wsp. 2012) oraz Europy: Francja (Delecolle i Lot 1981), Włochy (Bellardi i wsp. 1995; Dovas i Vovlas 2003), Niemcy, Holandia (Tsuneyoshi i wsp. 1998b), Grecja (Dovas i wsp. 2001), Czechy (Klukácková i wsp. 2007), Iran (Shahraeen i wsp. 2008), Polska (Chodorska i wsp. 2014c; Winiarczyk i wsp. 2014) i Serbia (Vucurovic i wsp. 2015).

W Grecji skala porażenia upraw przez GarCLV była różna i w zależności od regionu osiągała wartość 97,6\% w prowincji Arkadia położonej na półwyspie Peloponez, natomiast w prowincji Evia zaledwie 18\% (Dovas i wsp. 2001). We Włoszech Dovas i Vovlas (2003) notowali 
23-28\% chorych roślin, a w Meksyku, Pérez-Moreno i wsp. (2007) - 32,3\%. W Polsce, Chodorska i wsp. (2014b) oraz Winiarczyk i wsp. (2014) wykrywali GarCLV w 86-88\% testowanych prób. Na terenie Argentyny odnotowano porażenie upraw czosnku pospolitego w zakresie 52,6-70\% (Torrico i wsp. 2015). Pomimo stwierdzenia obecności GarCLV w większości rejonów świata, dotychczas nie opublikowano żadnych danych dotyczących strat $\mathrm{w}$ plonie roślin porażonych przez ten wirus. Zwykły utajony wirus czosnku przenoszony jest wraz $\mathrm{z}$ materiałem rozmnożeniowym oraz w sposób nietrwały przez kilka gatunków mszyc (van Dijk 1993b; Barg i wsp. 1994, 1997).

\section{Utajony wirus szalotki - występowanie, szkodliwość, epidemiologia / Shallot latent virus - occurrence, harmfulness and epidemiology}

Utajony wirus szalotki (Shallot latent virus, SLV) zakwalifikowany do rodzaju Carlavirus został po raz pierwszy wykryty i zidentyfikowany w roślinach czosnku askalońskiego (Allium ascalonicum L.), znanego powszechnie pod nazwą cebula szalotka, pochodzącego z pól zlokalizowanych w Holandii (Bos i wsp. 1978). Lee i wsp. (1979) określili izolaty SLV wykrywane w roślinach czosnku pospolitego jako nowy gatunek wirusa i nadali mu nazwę utajony wirus czosnku (Garlic latent virus, GLV). Jednakże, porównanie właściwości biologicznych i molekularnych wskazywało, że wykryte izolaty są izolatami SLV (van Dijk 1993b; Tsuneyoshi i wsp. 1998b). Obecnie doniesienia o wykrywaniu wirusa $\mathrm{w}$ roślinach czosnku pospolitego pochodzą z terenów Ameryki Południowej: Argentyna (Torrico i wsp. 2010), Brazylia (Mituti i wsp. 2011), Ameryki Północnej: Meksyk, Australii (Wylie i wsp. 2012), Azji: Tajwan (Tsuneyoshi i wsp. 1998b), Chiny (Chen i wsp. 2001b; Wylie i wsp. 2012), Iran (Shahraeen i wsp. 2008) oraz Europy: Niemcy (Paludan 1980), Hiszpania (Wylie i wsp. 2012) i Polska (Chodorska i wsp. 2014c).

Dane literaturowe wskazują, że SLV wykrywano w Iranie (3,9\% testowanych prób) (Shahraeen i wsp. 2008) oraz Brazylii (3\% testowanych prób) (Mituti i wsp. 2011, 2015). Natomiast w Polsce, Chodorska i wsp. (2014c) stwierdzali SLV w 79\% testowanych roślin czosnku pospolitego. Podobnie, jak w przypadku GarCLV W literaturze światowej nie ma doniesień na temat strat w plonie czosnku pospolitego wynikających z porażenia roślin przez SLV.

Utajony wirus szalotki przenoszony jest podczas wegetatywnego rozmnażania roślin oraz w sposób nietrwały przez mszycę szklarniową wielożerną (Myzus ascalonicus Doncaster) i mszycę trzmielinowo-burakową (A. fabae) (Bos i wsp. 1978).

\section{Carlawirusy porażające czosnek pospolity - budowa genomu / Carlaviruses associated with garlic plants - genome structure}

Cząstki GarCLV i SLV są nitkowate (610-700 nm długości i 12-15 nm średnicy). Genom stanowi pojedyncza nić RNA wielkości 7400-7900 pz. W genomie tych wirusów odnotowano występowanie sześciu otwartych ramek odczytu kodujących 6 funkcjonalnych białek. Stwierdzono również występowanie konserwatywnych domen - domeny AAFD charakterystycznej dla wirusów o nitkowatej budowie wirionu (Koonin i wsp. 1993) oraz TGGXXG, która jest domeną specyficzną dla gatunków należących do rodzaju Carlavirus (Hataya i wsp. 2000).

\section{Zróżnicowanie genetyczne populacji carlawirusów pochodzących z roślin czosnku pospolitego / Genetic diversity of Carlavirus populations originated from garlic plants}

Badania przeprowadzone przez Pramesh i Baranwal (2013) wykazały, że podobieństwo sekwencji nukleotydów genu kodującego białko płaszcza izolatów GarCLV dostępnych w banku genów (GenBank) pochodzących z Indii, Japonii, Korei Południowej, USA, Chin i Australii wyniosło, odpowiednio, $88,1-99,8 \%$ oraz $91,5-100 \%$ na poziomie nukleotydów i aminokwasów. Porównanie sekwencji nukleotydów genu kodującego CP polskich izolatów GarCLV z sekwencjami wszystkich dostępnych w banku genów izolatów wirusa, przeprowadzone przez Chodorską i wsp. (2014c) wykazało podobieństwo na poziome $85-91 \%$. Przedstawione wyniki badań dowodzą, że zróżnicowanie sekwencji obejmujących gen kodujący $\mathrm{CP}$ izolatów wirusa pochodzących $\mathrm{z}$ różnych rejonów świata jest wysokie. Analiza porównawcza sekwencji w obrębie genu kodującego CP wszystkich dostępnych w banku genów izolatów GarCLV wykazała podobieństwo między tymi sekwencjami na poziomie 80,3-97,6\% (Torrico i wsp. 2015).

Badania przeprowadzone przez Arya i wsp. (2009) wykazały, że sekwencje nukleotydów genu kodującego CP indyjskich izolatów SLV są najbardziej podobne do sekwencji chińskich i japońskich izolatów (83-98\%). Mituti i wsp. (2011) wskazują, że podobieństwo sekwencji nukleotydów fragmentu genu kodującego CP izolatu pochodzącego z Brazylii oraz izolatu YH1 pochodzącego z Chin wyniosło $87 \%$. Podobne wyniki badań uzyskali Chodorska i wsp. (2014c), którzy wykazali, że sekwencje nukleotydów genu kodującego CP siedmiu polskich izolatów SLV były najbardziej podobne do homologicznej sekwencji nukleotydów izolatu pochodzącego z Chin (ACC. No. AF314147). Z badań przeprowadzonych przez Wylie i wsp. (2014) wynika, że sekwencje nukleotydów genu kodującego CP izolatów pochodzących z Australii, Chin, Meksyku i Hiszpanii są podobne w 95-100\%.

\section{Podsumowanie / Summation}

Przedstawione w pracy cztery gatunki wirusów należą do dwóch różnych rodzajów - Carla- i Potyvirus. Ważną, cechą wspólną zaprezentowanych gatunków wirusów jest to, że wszystkie przenoszą się podczas wegetatywnego rozmnażania roślin czosnku, co ponadto, jest jedyną drogą uzyskania roślin potomnych czosnku pospolitego oraz wszystkie przenoszone są przez wektory - kilka gatunków mszyc. W związku z powyższym podjęcie skutecznych działań zapobiegawczych wymaga kontroli populacji mszyc na polach oraz prawidłowej diagnostyki wirusologicznej. Szerokie rozpowszechnienie wirusów na terenie 
światowych upraw czosnku, świadczyć może o zbyt późnych działaniach podjętych w celu oceny stanu zagrożenia pól produkcyjnych przez wirusy. Rozpoznanie infekcji wirusowych na podstawie obserwowanych objawów jest niewystarczające ze względu na jednoczesne występowanie kilku wirusów wywołujących objawy chorobowe - tzw. infekcje mieszane. Niezbędna jest identyfikacja wszystkich, obecnych w roślinach patogenów przy użyciu metod serologicznych oraz technik molekularnych. Ograniczenie roli chorób wirusowych w uprawach czosnku możliwe jest jedynie poprzez regularną kontrolę fitosanitarną oraz ograniczanie populacji wektorów.

\section{Literatura / References}

Arya M., Baranwal V.K., Ahlawat Y.S., Singh L. 2006. RT-PCR detection and molecular characterization of Onion yellow dwarf virus associated with garlic and onion. Current Science 91: 1230-1234.

Arya M., Majumder S., Baranwal V.K. 2009. Partial characterization of coat protein gene of Shallot latent virus associated with garlic in India. Indian Journal of Virology 20 (1): 9-11.

Baghalian K., Kim O.K., Natzuaki K.T. 2010. Molecular variability and genetic structure of the population of Onion yellow dwarf virus infecting garlic in Iran. Virus Genes 41: 282-291.

Barg E., Lesemann D.E., Vetten H.J., Green S.K. 1994. Identification, partial characterization, and distribution of viruses infecting allium crops in South and Southeast Asia. Acta Horticulturae 358: 251-258.

Barg E., Lesemann D.E., Vetten J., Green S.K. 1997. Viruses of Allium and their distribution in different Allium crops and geographical regions. Acta Horticulturae 433: 607-616.

Bellardi M.G., Marani F., Betti L., Rabiti A.L. 1995. Detection of Garlic common latent virus (GCLV) in Allium sativum L. in Italy. Phytopathologia Mediterranea 34: 58-61.

Bereda M., Paduch-Cichal E., Kalinowska E., Szyndel M.S. 2015. Genetic diversity and evidence of recombination in the coat protein gene of Onion yellow dwarf virus. European Journal of Plant Pathology 142 (2): 377-387.

Bos L. 1976. Onion yellow dwarf virus. C.M.I./A.A.B. Description of Plant Viruses No. 158. http://www.dpvweb.net/dpv/ showdpv.php?dpvno=158 [Accessed: 05.03.2016].

Bos L., Huttinga H., Maat D.Z. 1978. Shallot latent virus, a new carlavirus. Netherlands Journal of Plant Pathology 84: $227-237$.

Celli M.G., Torrico A.K., Kiehr M., Conci V.C. 2013. Striking differences in the biological and molecular properties of onion and garlic isolates of Onion yellow dwarf virus. Archives of Virology 158 (6): 1377-1382.

Chen J., Adams M.J., Zheng H.Y., Chen J.P. 2003. Sequence analysis demonstrates that Onion yellow dwarf virus isolates from China contain a P3 region much larger than other potyviruses. Archives of Virology 148: 1165-1173.

Chen J., Chen J.P., Adams M.J. 2001a. Characterization of some carla- and potyviruses from bulb crops in China. Archives of Virology 147: 419-428.

Chen J., Chen J.P., Adams M.J. 2001b. Molecular characterization of a complex mixture of viruses in garlic with mosaic symptoms in China. Archives of Virology 146: 1841-1853.

Chodorska M., Paduch-Cichal E., Kalinowska E., Gaczkowska O., Lis M., Sierant B., Szyndel M.S. 2014a. First report of Leek yellow stripe virus in foreign and polish garlic plants in central Poland. Journal of Plant Pathology 96 (4), p. S4.120.

Chodorska M., Paduch-Cichal E., Kalinowska E., Szyndel M.S. 2014b. Assessment of Allexiviruses infection in garlic plants in Poland. Acta Scientiarum Polonorum, Hortorum Cultus 13 (2): 176-186.

Chodorska M., Paduch-Cichal E., Kalinowska E., Szyndel M.S. 2014c. First report of Onion yellow dwarf virus, Garlic common latent virus and Shallot latent virus on garlic in Poland. Plant Disease 98 (6), p. 858.

Conci V.C., Canavelli A., Lunello P. 2003. Yield losses associated with virus-infected garlic plants during five successive years. Plant Disease 87: 1411-1415.

Conci V.C., Helguera M., Nome S.F. 1999. Serological and biological comparison of Onion yellow dwarf virus from onion and garlic in Argentina. The Fitopatologia Brasileira 24: 73-75.

Conci V.C., Nome S.F., Milne R.G. 1992. Filamentous viruses of garlic in Argentina. Plant Disease 76: 594-596.

Delecolle B., Lot H. 1981. Viroses de l'ail: I.-Mise en évidence et essais de caractérisation par immunoélectromicroscopie d'un complexe de trois virus chez différentes populations d'ail atteintes de mosaïque. Agronomie 1: 763-769.

Dovas C.I., Hatziloukas E., Salomon R., Barg E., Shiboleth Y., Katis N.I. 2001. Incidence of viruses infecting Allium spp. in Greece. Phytopathology 149: 1-7.

Dovas C.I., Vovlas C. 2003. Viruses infecting Allium spp. in southern Italy. Journal of Plant Pathology 85 (2), p. 135.

Elnagar S., Abdel-Kader El-Sheikh M., Salah El-Deen Abd El-Wahab A. 2011. Effect of natural infection with Onion Yellow Dwarf Virus (OYDV) on yield of onion and garlic crops in Egypt. Journal of Life Sciences 5 (8): 634-638.

Etoh T. 1985. Studies on the sterility in garlic Allium sativum L. Memoirs of Faculty of Agriculture Kagawa University 21: 7-132.

Fajardo T.V.M., Nishijima M., Buso J.A., Torres A.C., Ávila A.C., Resende R.O. 2001. Garlic viral complex: identification of potyviruses and carlavirus in central Brazil. Fitopatologia Brasileira 26: 619-626.

Fayad-André M.S., Dusi A.N., Resende R.O. 2011. Spread of viruses in garlic fields cultivated under different agricultural production systems in Brazil. Tropical Plant Pathology 36 (6): 341-349.

Fidan H. 2009. First report Garlic Common Latent Virus in garlic in Turkey. Journal of Plant Pathology 91 (4), p. 112.

Fidan H., Baloglu S. 2009. First report of Onion yellow dwarf virus and Leek yellow stripe virus in garlic in Turkey. Plant Disease $96(6)$, p. 672.

Fidan H., Çağlar B.K., Baloğlu S., Yılmaz M.A. 2015. Urginea maritime (L.) is a new host of Allexivirus group on onion and garlic plants in Turkey. Acta Horticulturae 1002: 309-312.

Gawande S.J., Gurav V.S., Ingle A.A., Gopal J. 2014. First report of Leek yellow stripe virus in Allium sativum in Western India. Plant Disease 98 (7), p. 1015. 
Ghosh D.K., Ahlawat Y.S. 1997. Filamentous viruses associated with mosaic disease of garlic in India. Indian Phytopathology 50: $266-276$.

Gupta N., Prabha K., Islam S., Baranwal V.K. 2013. First report of Leek yellow stripe virus in garlic from India. Journal of Plant Pathology 95 (4), p. S4.75.

Hamed K., Menzel W., Mohamed M.E., Bakheet K.A., Winter S. 2013. First report of Garlic common latent virus infecting garlic in Sudan. Plant Disease 97 (4), p. 562.

Hataya T., Uchino K., Arimoto R., Suda N., Sano T., Shikata E., Uyeda I. 2000. Molecular characterization of Hop latent virus and phylogenetic relationships among viruses closely related to carlaviruses. Archives of Virology 145: 2503-2524.

Jemal K., Abraham A., Feyissa T. 2015. The occurrence and distribution of four viruses on garlic (Allium sativum L.) in Ethiopia. International Journal of Basic and Applied Sciences 4 (1): 5-11.

Klukáčková J., Navrátil M., Duchoslav M. 2007. Natural infection of garlic (Allium sativum L.) by viruses in the Czech Republic. Journal of Plant Diseases Protection 114 (3): 97-100.

Klukáčková J., Navrátil N., Veselá M., Havránek P., Šafářová D. 2004. Occurrence of garlic viruses in the Czech Republic. Acta Fytotechnica et Zootechnica 7: 126-128.

Kobayashi K., Rabinowicz P., Bravo-Almonacid J.F., Helguera M., Conci V., Lot H., Mentaberry A. 1996. Coat protein gene sequences of garlic and onion isolates of the Onion yellow dwarf potyvirus (OYDV). Archives of Virology 141: 2277-2287.

Koch L., Salomon R. 1994. Serological detection of Onion yellow dwarf virus in garlic. Plant Disease 78: 785-788.

Koonin E.V., Dolja V.V., Morris J.T. 1993. Evolution and taxonomy of positive-strand RNA viruses: implications of comparative analysis of amino acid sequences. Critical Reviews in Biochemistry and Molecular Biology 28: 375-430.

Kumar P., Dhawan P., Mehra R. 2011. Characterization, transmission and host range of Onion yellow dwarf virus. Plant Disease Research 26 (2), p. 176.

Lee Y.W., Yamazaki S., Osaki T., Inouye T. 1979. Two elongated viruses in garlic, Garlic latent virus and Garlic mosaic virus. Journal of Phytopathology 45 (5): 727-734.

Lot H., Chovelon V., Souche S., Delecolle B. 1998. Effects of Onion yellow dwarf and Leek yellow stripe viruses on symptomatology and yield loss of three French garlic cultivars. Plant Disease 82: 1381-1385.

Majumder S., Baranwal V.K. 2009. First report of Garlic common latent virus in garlic from India. Plant Disease 93 (1), p. 106.

Majumder S., Baranwal V.K., Joshi S. 2008. Simultaneous detection of Onion yellow dwarf virus and Garlic latent virus in infected leaves and cloves of garlic by duplex RT-PCR. Journal of Plant Pathology 90: 369-372.

Marys E., Carballo O., Izaguirre-Mayoral M.L. 1994. Isolation and characterization of viruses present in four clones of garlic (Allium sativum) in Venezuela. Journal of Phytopathology 142 (4): 227-234.

Melhus I.E., Reddy C.S., Henderson W.J., Vestal E.F. 1929. A new virus disease epidemic on onions. Phytopathology 19, p. 73.

Messiaen C.M., Lot H., Delecolle B. 1994. Thirty years of France' experience in the production of disease-free garlic and shallot mother bulbs. Acta Horticulturae 358: 275-279.

Milosevic D., Gvozdanovic-Varga J., Ignajtov M., Nikolic Z., Vucurovic I., Vucurovic A., Stankovic I. 2015. First report of Onion yellow dwarf virus infecting shallot in Serbia. Plant Disease 99 (10), p. 1450.

Mituti T., Marubayashi J.M., Moura M.F., Krause-Sakate R., Pavan M.A. 2011. First report of Shallot latent virus in garlic in Brazil. Plant Disease 95 (2), p. 227.

Mituti T., Moura M.F., Marubayashi J.M., Oliveira M.L., Imaizumi V.M., Sakate R.K., Pavan M.A. 2015. Survey of viruses belonging to different genera and species in noble garlic in Brazil. Scientia Agricola 72 (3): 278-281.

Mohamed N.A., Young B. 1980. Leek yellow stripe virus in New Zealand. New Zealand Journal of Agricultural Research 23 , p. 129.

Mohammed H.S., Zicca S., Manglli A., Mohamed M.E., El Siddig M.A.R., El Hussein A.A., Tomassoli L. 2013. Occurrence and phylogenetic analysis of Potyviruses, Carlaviruses and Allexiviruses in garlic in Sudan. Journal of Phytopathology 161 (9): 642-650.

Navratil M., Safarova D., Tkadlecova E., Klukáčková J. 2006. Molecular characterization of Czech and Chinese Leek yellow stripe virus isolates from garlic. Acta Virologica 50 (3): 207-210.

Nicto A.M., Conci V.C., Conci L.R. 2004. Nucleotide sequence of the 3' region of a Carlavirus from Argentinean garlic mosaic. International Symposium on Edible Alliaceae. China, Beijing, 04.2004, p. 103.

Paludan N. 1980. Virus attack on leek: survey, diagnosis, tolerance of varieties and winter hardiness. Tidsskrift for planteavl 84: 371-385.

Pappu H.R., Hellier B.C., Dugan F.M. 2005. First report of Onion yellow dwarf virus, Leek yellow stripe virus, and Garlic common latent virus in garlic in Washington State. Plant Disease 89, p. 205.

Parrano L., Afunian M., Pagliaccia D., Douhan G., Vidalakis G. 2012. Characterization of viruses associated with garlic plants propagated from different reproductive tissues from Italy and other geographic regions. Phytopathologia Mediterranea 51 (3): 549-565.

Perez-Moreno L., Cordova-Rosales Z., Barboza-Corona E., Ramirez-Malagon R., Ramirez-Lua J., Ruiz-Castro S., Silva-Rosales L. 2006. First report of Leek yellow stripe virus in garlic in the State of Guanajuato, Mexico. Plant Disease 90 (11), p. 1458.

Pérez-Moreno L., Córdova-Rosales Z.V., Rico-Jaramillo E., Ramírez-Malagón R., Barboza-Corona E., Zúñiga-Zúñiga J., Ruiz-Castro S., Silva-Rosales L. 2007. Identificación de virus fitopatógenos en ajo (Allium sativum L.), en el Estado de Guanajuato, México. Revista Mexicana de Fitopatología 25: 11-17.

Pramesh D., Baranwal V.K. 2013. Molecular characterization of coat protein gene of Garlic common latent virus isolates from India: an evidence for distinct phylogeny and recombination. Virus Genes 47: 189-193.

Riechmann J.L., Lain S., Garcia J.A. 1992. Review Article: Highlights and prospects of potyvirus molecular biology. Journal of General Virology 73 (1): 1-16.

Saffar Z.N., Torabi S., Naghavi M., Golnaraghi A.R., Aryakia E. 2013. Onion yellow dwarf virus on leek, onion, shallot and welsh onion in Iran. Journal of Plant Pathology 95 (4), p. S4.73.

Shahraeen N., Lesemann D.E., Ghotbi T. 2008. Survey for viruses infecting onion, garlic and leek crop in Iran. EPPO Bulletin 38 (1): 131-135.

Simon P.W., Jenderek M.M. 2003. Flowering, seed production and the genesis of garlic breeding. Plant Breeding Reviews 32: $211-244$. 
Soliman A.M., Mahmoud S.Y.M., Dawood R.A. 2012. Molecular characterization of Onion yellow dwarf virus (garlic isolates) with production of virus-free plantlets. International Journal of Virology 8 (1): 61-70.

Sutarya R. 1994. Virus disease of shallot and garlic in Java, and prospects for their control. Acta Horticulturae 369: 134-143.

Sward R.J., Brennan A.P. 1994. Diagnosis and control of allium virus diseases in Victoria, Australia. Acta Horticulturae 358: $295-298$.

Szyndel M.S. 1997. The occurrence of virus inclusions as the cytological evidence of garlic plants infection by poty- and carlaviruses. Phytopathologia Polonica 14: 29-34.

Takaichi M., Nagakubo T., Oeda K. 2001. Mixed virus infections of garlic determined by a multivalent polyclonal antiserum and virus effects on disease symptoms. Plant Disease 85 (1): 71-75.

Takaki F., Sano T., Yamashita K. 2006. The complete nucleotide sequence of attenuated Onion yellow dwarf virus: a natural potyvirus deletion mutant lacking the N-terminal amino acids of HC-Pro. Archives of Virology 151 (7): 1439-1445.

Takaki F., Sano T., Yamashita K., Fujita T., Ueda K., Kato T. 2005. Complete nucleotide sequences of attenuated and severe isolates of Leek yellow stripe virus from garlic in northern Japan: Identification of three distinct virus types in garlic and leek world-wide. Archives of Virology 150 (6): 1135-1149.

Torrico A.K., Cafrune E.E., Conci V.C. 2010. First report of Shallot latent virus in garlic in Argentina. Plant Disease 94, p. 915.

Torrico A.K., Celli M.G., Conci L.R., Conci V.C. 2015. Incidence of Garlic common latent virus in Argentina, and phylogenetic and recombination analyses of isolates. Pesquisa Agropecuária Brasileira 50: 363-373.

Tsuneyoshi T., Matsumi T., Natsuaki K.T., Sumi S. 1998a. Nucleotide sequence analysis of virus isolates indicates the presence of three Potyvirus species in Allium plants. Archives of Virology 143: 97-113.

Tsuneyoshi T., Matsumi T., Deng T.C., Sako I., Sumi S. 1998b. Differentiation of Allium carlaviruses isolated from different parts of the world based on the viral coat protein sequence. Archives of Virology 143: 1093-1107.

van Dijk P. 1991. Mite-borne virus isolates from cultivated Allium species and their classification into two new rymoviruses in the family Potyviridae. Netherlands Journal of Plant Pathology 97: 381-399.

van Dijk P. 1993a. Survey and characterization of potyviruses and their strains in Allium species. Netherlands Journal of Plant Pathology 99 (2): $1-48$.

van Dijk P. 1993b. Carlavirus isolates from cultivated Allium species represent three viruses. Netherlands Journal of Plant Pathology 99 (5): $233-257$.

Verhoyen M., Horvat F. 1973. La striure chlorotique du porreau. 1. Identificatin e l'agent causal. Parasitica 29, p. 16.

Verma R.K., Mishra R., Sharma P., Choudhary D.K., Gaur R.K. 2014. Systemic infection of Potyvirus: A Compatible interaction between host and viral proteins. p. 353-363. In: "Approaches to Plant Stress and their Management" Edition: first, Chapter: Systemic Infection of Potyvirus: A Compatible Interaction Between Host and Viral Proteins (R.K. Gaur, Predeep sharm, eds.). Springer India, DOI 10.1007/978-81-322-1620-9 20.

Vucurovic A., Vucurovic I., Stankovic I., Bulajic A., Nikolic D., Teodorovic S., Krstic B. 2015. First report of Garlic common latent virus infecting garlic in Serbia. Plant Disease 99 (6), p. 894.

Winiarczyk K., Solarska E., Sienkiewicz W. 2014. Prevalence of infections with Onion yellow dwarf virus, Leek yellow stripe virus and Garlic common latent virus in plants from the genus Allium. Acta Scientiarum Polonorum, Hortorum Cultus 13 (3): 123-133.

Wylie S.J., Li H., Jones M.G.K. 2012. Phylogenetic analysis of allexiviruses identified on garlic from Australia. Australasian Plant Disease Notes 7: 23-27.

Wylie S.J., Li H., Saqib M., Jones M.G.K. 2014. The global trade in fresh produce and the vagility of plant viruses: a case study in garlic. PLoS ONE 9 (8), p. e105044.

Yoshida N., Shimura H., Yamashita K., Suzuki M., Masuta C. 2012. Variability in the P1 gene helps to refine phylogenetic relationships among Leek yellow stripe virus isolates from garlic. Archives of Virology 157 (1): 147-153. 